\title{
DYNAMIC OF PARANOID SYNDROMES IN SCHIZOPHRENIA IN DEPENDENCE ON DELUSIONS OF BEING CONTROLLED
}

\author{
Stefan Todorov ${ }^{1}$, Mariana Arnaoudova ${ }^{2}$, Koralia Todorova ${ }^{3}$ \\ 1) MHAT "St. Marina" - Varna \\ 2) Third Psychiatric Clinic MHAT "St. Marina" - Varna \\ 3) First Psychiatric Clinic MHAT "St. Marina" - Varna \\ Department of Psychiatry, Medical University, Varna, Bulgaria
}

\section{SUMMARY:}

Delusions of being controlled are psychotic symptoms among the most characteristic symptoms of schizophrenia. The aim of our study was to explore the dynamic of paranoid syndromes in schizophrenia in dependence on delusions of outside control. The objects were 160 schizophrenic patients, aged 18-65 years. We distinguished, conditionally, three consecutive, but not obligatory stages in the syndrome dynamic. The first stage is characterized by sense of "loss of Ego-control" on separate psychic functions, not engaged with a concrete outside influence. On the second stage the sense of "loss of Ego-control" concretizes and forms delusional conception of outside influence and control. On the third stage Egocontrol of one's own psychic processes is replaced by delusional conviction of outside control. A total depersonalization in the frame of paranoid syndrome is observed.

The clinical peculiarities of each stage of paranoid syndromes in dependence on the delusions of influence testify, to some extent, to one or other progression of schizophrenic process and could have a relatively prognostic value.

Key words: paranoid schizophrenia, delusions, outside control, mental automatism

\section{INTRODUCTION:}

Delusions of being controlled are psychotic symptoms, playing an important role among the group of characteristic symptoms of schizophrenia. They have a great significance not only as diagnostic criteria but in the dynamic of paranoid syndromes in paranoid schizophrenia $(3,5,9,13)$. On the other hand, they are the main symptoms, marking the boundaries of the mental automatism and are closely connected with some first rank symptoms of K. Schneider $(1939,1959)(6,7,8,10,11,12)$. He set out a list of symptoms, which would be most likely to lead to the diagnosis of schizophrenia, in the absence of organic brain disease.
AIM:

The aim of our study was to explore the dynamic of paranoid syndromes in dependence on delusions of outside control in a large number of schizophrenic patients.

\section{SUBJECTS AND METHODS:}

The objects of the study were 160 patients (68 males, 92 females), aged 18-65 years. The patients were repeatedly clinically examined and followed for a longer period of time (from 6 months to 5 years).

\section{RESULTS:}

Based on the results and their analysis, we distinguished, under condition, three consecutive, but not obligatory stages in the syndrome dynamic, including their enrichment with hallucinations and pseudohallucinations and transformation into paranoid-hallucinatory. In some cases the clinical picture of the syndromes remain on the same stage during the whole period of the illness, while in other- a consecutive transition from one to another stage is observed.

The first stage - the outside influence is concrete and is not accompanied by a developed delusional conception. It is rather felt and suspected by some indirect signs than realized. The loss and the affiliation to one's own psychic functions and acts coexist. This stage includes mostly verbal hallucinations and pseudohallucinations, commenting thoughts and acts, threatening or indifferent in content "peculiar" voices, the feeling of "transparency", proved by some gestures and actions towards surroundings, echo of someone's own thoughts. The appearance of alien thoughts is mostly felt, because of their unusual content or sensations, or senestopathy, etc. The first stage was observed in $143 /$ $89.37 \%$ / patients. Out of them in $52 / 36.36 \%$ / a complete clinical remission was reached, $91 / 56.87 \% /$ entered the second stage, and a very small part- $11 / 12.08 \%$ / reached the third stage.

On the second stage the feeling of outside influence distinctly concretizes and forms delusional conception of outside influence and control. A number of psychic experiences, sensations or psychomotor acts are ruminated 
as influenced or managed, inserted or withdrawn, but the total control is kept.

On the third stage delusions of being controlled affect the personality as a whole. The patient looses the feeling of his own personal activity. It is replaced by delusional conviction of outside control. One is "a marionette" in the hands of an outside power. /delusional conviction of total outside control/. Thus, one of the final variants of mental automatism is formed (4).

\section{DISCUSSION:}

The first stage of the paranoid syndrome is met in the earlier stages of schizophrenia and has a relatively favourable course, while the second and third stage- run more unfavourably. Thus, the different stages of the dynamic of paranoid syndromes reflect, to a certain extent, the different phases of development of schizophrenia disorder. The reverse dynamic of the paranoid syndromes, in dependence of delusions of outside influence, due to pharmacological treatment, shows some peculiarities; starts with them and subsequently the rest symptoms could resolve .At a different point of view, the dynamic of paranoid syndromes in dependence of delusions of outside influence, reflects the pathology of "Ego-sense" $(1,2)$.

The first stage is characterized by a sense of "loss of Ego-control" on separate psychic functions, not connected with a concrete outside power, but only suspected by some indirect signs.

On the second stage the sense of "loss of Ego-control" concretizes and forms delusional conception of outside influence and control, insertion of alien thoughts and/ or withdrawal of someone's owns, enforced speaking, enforced motor movements. The integrity of one's personality is still not affected. No disturbance of the distinction between "Selfconsciousncess" and "Object-consciousness", from outside world is present. The second stage was more continuous, despite the adequate treatment and the greater part of the patients experienced partial remission, accompanied by short exacerbations, successfully managed.

On the third stage the "Ego-control" of one's own psychic processes and acts is completely destroyed. It is replaced by the delusional conviction of total outside control. One is "a marionette" in the hands of an outside power without any conforming with his wishes, needs, necessities. A total depersonalization is observed and one of the syndromes of psychic automatism is completely formed.

It is interesting to note, that a certain reduction of the intensity of the delusions of influence in the patients, who suffered the third stage of paranoid dynamic was observed too. As a consequence, the patients were not fully convicted as being physically or mentally controlled.

\section{CONCLUSION:}

The clinical peculiarities of each stage of paranoid syndromes in dependence on the delusions of influence testify, to some extent, to one or other type of progression of schizophrenic process and could have a relatively prognostic value. In this content, the first stage is characteristic for a more favourable course, while the second or third stage /with exception of paraphrenia states/ -for a more unfavourable one.

\section{REFERENCES:}

1. Меграбян АА. Деперсонализация. Ереван 1962. (in Russian)

2. Меграбян АA. Пихическое отчуждение-ведущее звено в формировании психопатологии шизофрении. Ж. Невропатол. И психиатр. 1975; 9:1351-1354. (in Russian)

3. Снежневский АВ. Симптоматология и нозология. В Шизофрения. Клиника и патогенеза. П/p А. В. Снежневского. М., Медицина 1969: 5-29. (in Russian)

4. Тодоров С, Арнаудова М, Тодорова К. Клинични съотношения между синдрома на психичен автоматизъм и деперсонализацията при шизофрения. Известия на съюза на учените - Варна, Серия медицина и екология, 1'2009; (XIV):18-20. (in Bulgarian)

5. Berner P, Katschnig H, Lenz G.
First-Rank Symptoms and Bleuler's Basic symptoms. New Results in Applying the Polydiagnostic Approach. Psychopathology 1986;19(5):244-252. [PubMed].

6. Clerambault G. de L' automatisme mental. L' Encephale 1927; 7: 567-568.

7. Clerambault G. de L' automatisme mental. Oeuvre psychiatrique. (Ed.) J. Fretet. Paris, Presses universitaire de France 1942: 527-576.

8. Colonna L. L'automatisme mental. Entretiens psychiatriques 1964; 13: 45-65.

9. Kimhy D, Goetz R, Yale S, Corcoran C, Malaspina D. Delusions in Individuals with Schizophrenia: Factor Structure, Clinical Correlates, and Putative Neurobiology. Psychopathology 2005 Nov-Dec; 38(6):338-44. Epub 2005 Nov 1. [CrossRef] [PubMed]
10. Lerner V, Kaptsan A, Witztum E. Kandinsky-Clerambault's Syndrome: concept of use for Western psychiatry. Isr J Psychiatry Relat Sci 2003; 40(1):4046.[PubMed].

11. Schneider K. Funf Jahre klinische Erfahrung an der Forschungsanstalt fur Psychiatrie. Dtsch. Med. Wochenschr. 1939; 62: 957-971.

12. Schneider K. Primare und Sekundare Symptome bei der Schizophrenie. Fortschr. Neur. Psychiat. 1957; 9: 487-490.

13. Weinberger RD, Harrisson PJ. Schizophrenia, Third Edition. Blackwell Publishing Ltd, 2011. Published Online: 8 Mar 2011. [CrossRef]

\footnotetext{
Address for correspondence:

Mariana Arnaoudova-Jekova, MD, PhD

Third Psychiatric Clinic MHAT "St. Marina"

1, Hristo Smirnenski str, 9010 Varna, Bulgaria; Mobile: +359 888512627

e-mail: marnaudova@hotmail.com
} 